Comissões d'Agricultura

Verba secreta, eleições,

Permitem manter o dente

Dos ministros na nação.

Hum! Oh que cheirinho!

Hum! Que petisqueira!

Ah! Que o Cotegipe

Nos prepara a pepineira (bis)

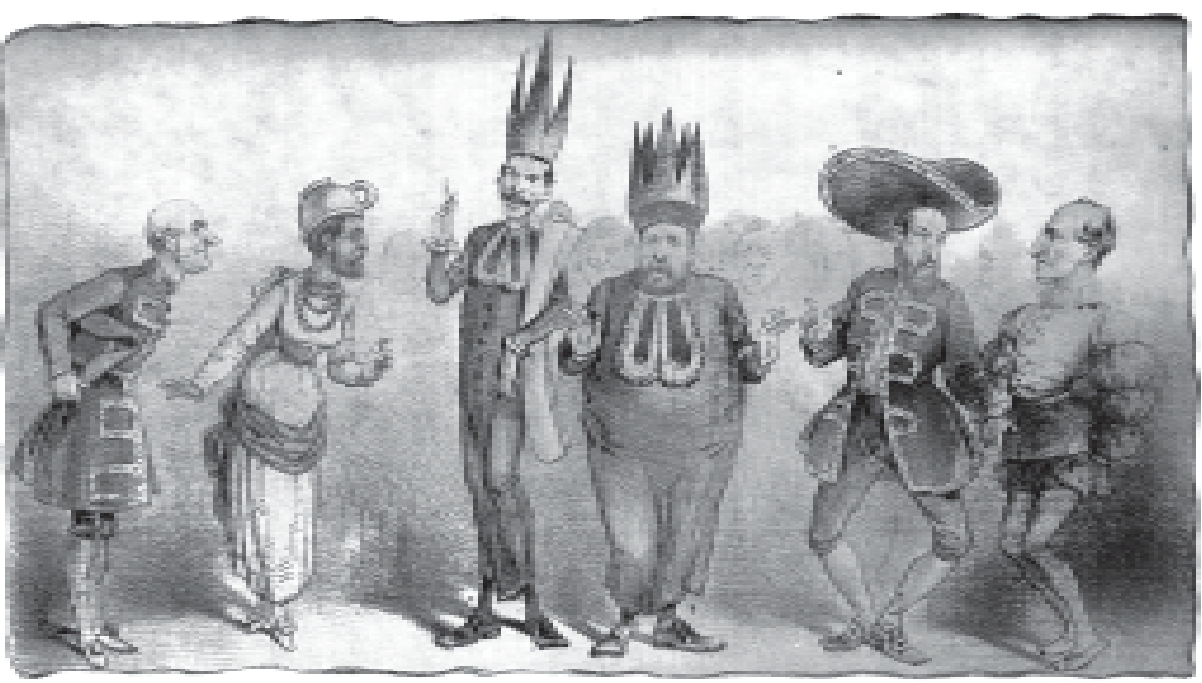

Faria. O Mequetrefe. Publicado em 01/09/1876. Reprodução; História da caricatura no Brasil, Herman Lima, Livraria José Olympio Editora, 1963, v. 1, p. 219. 


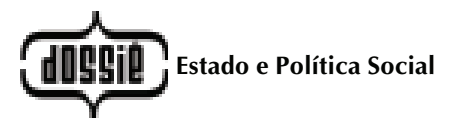

\title{
Maria Lucia Teixeira Werneck Vianna* \\ Voz, Alívio e Oportunidade ou a Política Social de Arquimedes no Brasil. Receita infalível ou abordagem discutível?
}

\author{
Resumo: O texto repõe em discussão o conceito de política social, desde \\ sempre desafiador, e polemiza prática muito cara à democratização do Estado: \\ a gestão participativa. Seu objetivo é questionar o caráter consensual que \\ vem sendo impresso a essas idéias e práticas provocando o debate sobre as \\ premissas teóricas que asfundamentam. Resumindo a trajetória da política \\ social no ocidente, a autora mostra as relações entre diferentes padrões de \\ proteção social e as diversas concepções da "questão social" dando voz ao \\ silêncio que se tem feito sobre a questão central e permanente da política \\ social: a desigualdade. \\ Palavras-chave: Política Social; Política Pública; Participação.
}

\begin{abstract}
The paper brings back the concept of social policy and defies supposed to be innovative practices of participation in management of public policies. Its main goal is to provoke the theoretical discussion over the foundations of social policy and its controversial relations to public policies mainly those of the welfare states concerned with social justice and individual freedom, with poverty and inequality.

Key-words: Social Policy; Public Policy; Participation.
\end{abstract}

"Dêem-me uma alavanca e um ponto de apoio e moverei o mundo" (frase atribuída a Arquimedes no século III A.C.)

\section{Introdução}

Há expressões que se instalam no léxico governamental, adentram o meio acadêmico e passam a fazer parte do vocabulário corrente como se sempre - e sem qualquer dúvida acerca de sua identidade - tivessem habitado esses espaços. Política social é uma delas. Como modalidade de política pública, outra expressão que sofre de mal similar, tornou-se um objeto que transita do plano da realidade para o

* Professora adjunta do Instituto de Economia da UFRJ e coordenadora do Laboratório de Economia Política da Saúde e da Seguridade Social (LEPS/UFRJ). Endereco postal: Instituto de Economia, campus da Praia Vermelha, Av. Pasteur, 250, Térreo, Urca, Rio de Janeiro, CEP: 22290240. Endereço eletrônico: marilu@ie.ufrj.br 
plano da reflexão com inusitada desenvoltura, quase que se transformando, por obra de uma ativa e interativa parceria entre governo e academia, em "nova ciência aplicada"1. Ciência que, bem ao gosto de seu tempo, se apresenta asceticamente consensual e cuja aplicação, também ajustada aos tempos, agora de democracia, envolveria tanto procedimentos inovadores, como gestão participativa, quanto metas politicamente corretas, como empoderamento da cidadania. Alçadas à condição de unanimidade nacional, as práticas da política social (ou seria de uma certa política social?) e da participação social (ou seria da comunidade?), essas janelas de oportunidade para emancipação dos cidadãos (ou seria dos pobres?) ganham a mídia e a boca do povo.

O texto que se segue tem a intenção de questionar o caráter consensual que vem sendo impresso às idéias de política social e gestão participativa - no Brasil, mas não só -, procurando suscitar (ou ressuscitar) um debate que a hipotética unanimidade omite: o debate em torno das premissas teóricas (controversas, por suposto) que, no campo das ciências sociais, fundamentam tais práticas e noções. A primeira seção consiste numa brevíssima tentativa de demonstrar a fluidez do conceito de política social no plano da reflexão. Na segunda, um resumo da trajetória da política social no Ocidente serve para enfatizar as relações que diferentes padrões de proteção social praticados no plano histórico da realidade guardam com também diferentes teorias sobre a questão social. A falácia do consenso no que concerne à política social predominante no Brasil atualmente é o foco da terceira seção, que prepara o terreno para as considerações tecidas na quarta (e última), a respeito da participação como procedimento característico da pretensa natureza inovadora dessa concepção de enfrentamento da questão social. ${ }^{2}$

\section{Uma pergunta sem resposta: o que é política social?}

Sempre citado quando se estuda política social, T. H. Marshall, em livro publicado em 1965 e reeditado seguidas vezes, em Londres, assinala aspectos interessantes para a reflexão sobre o tema. "Política social é um termo que, embora amplamente usado, não possui definição precisa. O significado que the é dado em contextos particulares é em grande medida matéria de conveniência ou convenção." Os referidos aspectos interessantes contidos no trecho se traduzem nos seguintes pressupostos: a) em contextos particulares, isto é, distintos, significados também distintos são atribuídos ao termo política social; b) tais distintos significados decorrem de conveniência ou convenção, ou seja, são estabelecidos mediante escolhas e/ou acordos. O primeiro sugere, enfatizando a imprescindível contextualização histórica,

\footnotetext{
Criada em 1989 e regulamentada em 2004, a carreira de Especialista em Políticas Públicas e Gestão Governamental oficializou, no âmbito do governo federal brasileiro, tanto a prática quanto o conceito de políticas públicas. Nos editais dos concursos para ingresso na carreira, realizados em vários anos, o tópico Políticas Públicas, entendido como campo de conhecimento indispensável a um gestor (equivalente à Ciência Política, à Economia, ao Direito), vem invariavelmente desdobrado nos itens tidos como demonstrativos de sua especificidade teórica: ao Direito), vem invariavelmente desdobrado nos itens tidos
conceituação, tipologias, fases de processamento e outros.

${ }^{2}$ A terceira e a quarta seções são versões resumidas, com leves alterações, de artigos publicados respectivamente nas revistas Praia Vermelha e Sociologias. Ver WERNECK VIANNA (2008 e 2009).

${ }^{3}$ MARSHALL (1975). Há tradução em português, publicada por Zahar editores, com o título Política Social, em 1967. O trecho citado não consta da edição brasileira porque foi incluído, pelo autor, na introdução especialmente escrita para a $4^{\text {a }}$ edição inglesa.
} 
I Voz, Alívio e Oportunidade ou a Política Social de Arquimedes no Brasil - VIANNA, M.L.T.W. \}

que se pode entender e praticar política social - que, como política pública, é ação de governo ${ }^{4}$ - de diversos modos, dependendo da natureza do Estado e dos processos decisórios em vigor que adjetivam a "a autoridade soberana do poder público" ${ }^{\text {. }}$. O segundo pressuposto chama a atenção para a importância de investigar os atores sociais e sua capacidade de negociar politicamente posições na agenda pública.

A despeito de apontar claramente as dificuldades que rondam a tarefa de conceituar política social, desqualificando a mística do consenso, a postulação de Marshall deixa de levar em conta a indagação que deveria, no plano da reflexão, ter precedência sobre qualquer outra: que referencial teórico abriga tal conceito? $\mathrm{Na}$ medida em que, abordando a política social como prática, permanece estritamente no plano da realidade (mesmo que considerando a sua dimensão histórica), Marshall passa ao largo de possíveis inquietações concernentes à esfera da teoria.

Todavia, o entendimento que tem da política social não é incorreto e talvez não seja sequer incompleto. Pois trata-se, com efeito, a política social, de uma prática, prática que recorre a saberes diversos tanto para ser formulada, como proposta de ação governamental, quanto para ser pensada, como objeto de análise acadêmica. As imprecisas definições de políticas públicas, não por acaso encontradas geralmente em textos de cientistas sociais americanos, corroboram o ponto.

EASTON, por exemplo, define a política pública (no original policy) como "uma teia de decisões que alocam valor" (1953, p.130); essa compreensão de que policies envolvem decisões ainda que não se confundam exatamente com elas, é compartilhada por vários autores. HAM \& HILL destacam as "implicações do fato que a política pública (no original policy) encerra mais um curso de ação ou uma teia de decisões do que uma decisão" (1984, p. 13); HECLO, cujos trabalhos pesam (no bom sentido) na estante de políticas sociais, além de admitir que o conceito de política pública não é "auto-evidente", afirma que "uma policy pode ser considerada como um curso de uma ação ou inação (não-ação), mais do que decisões ou ações específicas" (1972, p. 84). Políticas públicas, e por tabela políticas sociais, são, portanto, ações, "teias de decisões" que incidem sobre práticas.

Nesse nível de generalidade, o conceito de política pública (e, vale repetir, por tabela o de política social) encontra abrigo acolhedor no referencial teórico de um tipo de abordagem entre as muitas que povoam o campo da ciência política. Aquela que se debruça sobre processos decisórios contornando a complexidade dos mesmos por meio de sedutores diagramas. Na linguagem pragmática (e emblemática) de Easton, como resultantes (outputs) do processamento, pelo sistema político, de inputs - provenientes do meio ambiente - e, frequentemente, de withinputs - demandas e apoios originados no interior do próprio sistema político (EASTON, 1970). Uma vez que a ciência política não se constitui em pensamento

\footnotetext{
${ }^{4}$ RUA (1998, p. 232) observa que "por mais óbvio que possa parecer, as políticas públicas são 'públicas' - e não privadas ou apenas coletivas. Sua dimensão 'pública' é dada não pelo tamanho do agregado social sobre o qual incidem, mas pelo seu caráter 'imperativo'. Isso significa que uma de suas características centrais é o fato de que são decisões e ações revestidas da autoridade soberana do poder público".

${ }^{5}$ Monárquica ou republicana, federativa ou unitária, presidencialista ou parlamentarista, democrática ou autoritária e por aí vai.
} 
único, tal teoria pode ser perfeitamente substituída, no plano da reflexão, sem que se precise descartar a constatação, no plano da realidade, de que políticas públicas consistem em ações de governo.

Análises de políticas públicas requerem, porém, além das generalidades que a ciência política oferece - qualquer que seja a abordagem adotada - saberes específicos, já que se concretizam em ações específicas, setoriais. Áreas como saúde coletiva, planejamento urbano, desenvolvimento agrário, entre tantas, mobilizam saberes próprios para avaliar propostas, projetos e ações que configuram as práticas singulares rotuladas como políticas públicas. Na interdisciplinaridade, saudável em princípio e indispensável no caso, reside o germe da discórdia (entre os saberes aplicados das técnicas e os saberes generalistas das ciências sociais) e, também, o cerne das dificuldades teóricas para a conceituação de política pública, espremida que fica entre a generalidade de um saber e os particularismos de outros.

Ora, a política social, entendida como política pública, é uma prática. E, como sublinhado por Marshall, uma prática cujos objetivos constituem "matéria de convenção". Políticas de transporte coletivo ou de saneamento básico merecem a cunha de sociais tanto quanto as de saúde ou de assistência social, mas nem sempre a recebem. No plano da realidade, ou seja, do ângulo de sua concretização enquanto "teia de decisões e ações", a nomenclatura depende do "valor alocado", para citar, mais uma vez, Easton. Trocando em miúdos: o que é nomeado como política social em determinado contexto depende de escolhas que se manifestam no âmbito governamental, que, por seu turno, revelam a prevalência não só de uma dada percepção do que é social como, e sobretudo, de uma percepção seletiva dos aspectos do social dignos de intervenção.

No plano da reflexão, contudo, a política social, como tema, possui certas particularidades vis-à-vis a noção genérica de políticas públicas. $\mathrm{O}$ alvo maior da política social tem que ser pensado, antes de tudo, como o social (e não o transporte, a saúde ou a educação); o social apreendido como questão, cuja incorporação à agenda pública explicita sua natureza problemática ${ }^{6}$. Na perspectiva do analista, o objetivo (a ser investigado) do curso de ações governamentais referido como política social é, assim, a questão social, que pode (ou não) incluir transporte, saúde, educação, mas que só se formata setorialmente em decorrência de um reconhecimento anterior, tácito ou explícito: o reconhecimento de que a questão social encerra riscos à integridade da ordem social e que tais riscos derivam da própria estruturação da sociedade.

Desvendar os significados histórica e contingencialmente atribuídos à questão social constitui empreitada precípua das ciências sociais. Tal empreitada não se resume, entretanto, à descrição de como a ideia se cristaliza em diferentes realidades; explicar porque se cristaliza de uma forma ou de outra implica detectar, também, os fundamentos ideológicos e teóricos que balizam as opções. Posto que, por trás de definições da questão social e de ações governamentais adotadas para lidar com ela, estão necessariamente teorias sobre a realidade, formuladas com maior

\footnotetext{
Ver CASTEL (1998), especialmente Introdução e capítulo I.
} 
\} Voz, Alívio e Oportunidade ou a Política Social de Arquimedes no Brasil - VIANNA, M.L.T.W. \}

ou menor precisão, e que embutem, com maior ou menor recato, posturas ideológicas.

Embora as suposições acima enunciadas sejam insuficientes para enfrentar a densidade da matéria, servem de prelúdio ao presente artigo, afirmando seu ponto de partida: política social é um conceito que, por si, está longe de ser consensual. Quando abordado pela ótica da ciência social, então, não apenas as controvérsias se redobram como se propagam para aspectos que demandam um descolamento do plano da realidade para o plano da reflexão. Não obstante, esses planos mantêm uma estreita e promíscua relação e um rápido olhar sobre a evolução da política social no ocidente pode ajudar a esclarecer o argumento.

\section{Práticas históricas de política social e teorias} sobre a identidade da questão social

Ações governamentais com objetivos voltados para o enfrentamento da questão social começam a ser produzidas contemporaneamente à consolidação dos modernos Estados nacionais, no ocidente europeu, lá pelos séculos XVI e XVII. É então que se institucionaliza o que Weber considera o núcleo definidor do Estado moderno: o monopólio da violência legítima, e que se fazem presentes as condições que tornam possíveis e necessárias ações governamentais naquele sentido. Num contexto de transição para o capitalismo, de expansão do comércio e de fortalecimento das cidades, a pobreza se torna visível, incômoda, e passa a ser reconhecida como um risco social. A primeira fase da evolução da política social consistiu nas chamadas Leis dos Pobres, bastante disseminadas pelos países europeus, embora com diferenças marcantes entre eles. Ordenações de Estado, faziam compulsória a assistência paroquial, implicavam a criação de um fundo público e tinham por finalidade tirar os pobres das ruas ${ }^{7}$.

A pobreza, nesta fase, é o risco social predominante. O Estado age para proteger a sociedade da ameaça representada pela pobreza (à qual se associam a indigência, a doença, o furto, a degradação dos costumes) e para "proteger" os pobres. Como mostra Polanyi, sem a "proteção" levada a efeito pelas Leis dos Pobres seguramente as sociedades européias não teriam resistido aos cataclismos sociais produzidos pelas mudanças operadas com a mercantilização da produção e o advento do capitalismo (POLANYI, 1980). Quanto aos pobres, foram protegidos ora pela distribuição de alimentos, ora por meio de complementação salarial, ora através do recolhimento a asilos, ora mediante recrutamento para as manufaturas públicas. A pobreza e as formas de lidar com ela entram também na agenda dos pensadores. Jonathan Swift, o autor de Viagens de Gulliver, publica, em 1729, a sátira Uma Modesta Proposta, cujo subtítulo - Para Impedir que os Filhos de Gente Pobre da Irlanda sejam um Peso para os seus Pais ou o País; e para torná-los úteis

\footnotetext{
O modelo mais conhecido está nas Poor Laws inglesas, instituídas a partir de 1552, quando o registro dos pobres se tornou obrigatório em todo o Reino Unido, e consagradas na legislação promulgada por Elizabeth I, em 1601. A Lei dos Pobres, na Inglaterra, sofreu radical reforma em 1834, mas só foi revogada em 1948. Ver PIVEN \& CLOWARD (1971), POLANYI (1980), HECLO (1974), entre outros.
} 
ao Povo - é bastante revelador ${ }^{8}$. Mas pode-se considerar que tenha sido Locke o primeiro a formular, no âmbito da filosofia política moderna, uma teoria sobre a pobreza, entendendo-a como uma patologia social causadora de um prejuízo que "recai nos industriosos" ${ }^{9}$. Teórico liberal avant la lettre, Locke distingue os desvalidos dos "zangões mendicantes, que vivem do trabalho dos outros", denuncia o aumento do número de pobres como decorrente da insuficiência da legislação elizabethana e propõe medidas mais repressivas para enfrentar a mazela ameaçadora.

Leis dos Pobres funcionaram, historicamente, em tempos de monarquia absoluta ou governos oligárquicos. Já nos meados do século XIX, quando a produção industrial se ampliava a largos passos exigindo crescentemente mão-de-obra disposta ao assalariamento, e os preceitos liberais permeavam a institucionalidade política, as críticas a esta forma de proteção social se tornam mais severas e sofisticadas. A Economia Política, que consolidava seu estatuto de ciência nas obras de autores como David Ricardo, John Stuart Mill, Jeremy Benthan, Thomas Malthus e outros, vai destacar teoricamente a impossibilidade de convivência entre a ordem capitalista, para a qual se concebia imprescindível a autorregulação do mercado, e um sistema de salários subsidiados por fundos públicos ${ }^{10}$. Stuart Mill é um autor exemplar do debate que se trava, no plano da reflexão, sobre a questão social e as possibilidades de intervir sobre ela. Em Princípios de Economia Política, de 1848, identifica nos conflitos entre os trabalhadores e seus patrões a origem da natureza problemática do social, mas explica esses conflitos como parte da condição "embrutecida" da classe operária ${ }^{11}$. A educação, propiciando a superação do embrutecimento permitiria o reconhecimento de que os interesses de classe não são antagônicos; permitiria, ademais, que o trabalhador, tanto quanto o capitalista, assumisse e valorizasse sua autonomia individual. Proteção vinda do Estado estava, obviamente, descartada.

Em fins do século XIX, uma segunda fase da política social se inaugura. Seguros sociais compulsórios, para fazer face a riscos sociais associados ao trabalho assalariado, despontam como o modelo dominante de proteção social. No novo cenário, de capitalismo industrial consolidado, aparecem novos atores - sindicatos, partidos políticos - e arranjos institucionais capazes de incluir, na agenda pública, demandas de setores emergentes no mundo do trabalho. Na Inglaterra, as obras de Thomas Green, Leonard Hobhouse, John Hobson e os Webb, entre outros, revelam a mudança que se operava em termos da interpretação teórica da sociedade ${ }^{12}$. O

\footnotetext{
${ }^{8}$ A sátira foi incluída no volume Os 100 Melhores Contos de Humor da Literatura Universal, organizado por Flávio Moreira da Costa. Ediouro, Rio de Janeiro, 2001.

${ }^{9}$ Locke, Draft of a Representation Countaining a Scheme of Methods for the Employment of the Poor [1697], apud VÁRNAGY (2006)

${ }^{10}$ A reforma da Poor Law inglesa, em 1834, é esclarecedora. Precedida de intenso debate dominado pela idéia de que o mercado, e não o Estado, é que devia cuidar dos pobres, aboliu a concessão de qualquer "assistência externa" (abonos salariais e distribuição de alimentos) e reintroduziu a experiência dos albergues sob novo formato, pelo qual ficava a critério do candidato (o pobre) pleitear o "benefício" com o que, entretanto, perdia seu status de cidadão livre. 11 STUART MILL [1848] (1986, Livro Quarto, cap.VII). Vale lembrar que 1848 é o ano em que Marx e Engels publicam o Manifesto Comunista.

${ }_{12}^{2}$ Para MERQUIOR (1991), Lectures on the Principles of Political Obligation, a principal obra de Thomas Hill Green, publicada postumamente em 1886, foi a fonte inspiradora de Beveridge, constituindo-se numa "carta original para o Estado social britânico" (p. 155).
} 
pensamento de Durkheim, na França, é revelador da tentativa de fundamentar teoricamente a necessidade de proteger a sociedade dos riscos da anomia, bem como da preocupação com o papel das associações na geração de formas mais orgânicas de solidariedade ${ }^{13}$.

Para a sociedade, mais que a pobreza, a ameaça agora está na recusa ao assalariamento. Recusa que se expressa passivamente no absenteísmo (em razão de doença, de acidente, de maternidade, ou sem razão nenhuma) e ativamente, de forma anárquica como nos ataques e quebradeiras promovidos por trabalhadores ingleses em várias ocasiões, ou de forma organizada pelos sindicatos operários, crescentemente contestadores do próprio sistema capitalista. Para os trabalhadores, gradativamente se definem os riscos a que estão submetidos pela estrutura produtiva industrial: o acidente de trabalho, a cessação da capacidade laborativa, a doença, impedem temporária ou permanentemente o autossustento via mercado, única alternativa disponível.

O primeiro seguro social de que se tem notícia foi instituído por Bismarck, na Alemanha, nos anos 1880. Não resultou do jogo parlamentar como ocorreu, a partir de então, em vários outros países. Mas foi uma opção claramente política, que tinha por objetivo o enfrentamento do movimento operário e conformava uma proposta intencional de organização do universo do trabalho - o corporativismo submetido ao Estado - e de controle social - leia-se 'do' social (TAMPKE, 1981) ${ }^{14}$.

De todo modo, o modelo adotado por Bismarck, o seguro social, difundiuse rapidamente pela Europa. Na medida em que a democracia avançava, com a ampliação do direito ao voto, a legalização das centrais sindicais e a chegada dos partidos trabalhistas e social-democratas ao Parlamento, os seguros passaram a cobrir parcelas cada vez mais significativas de trabalhadores. A forma seguro, implicando um contrato entre partes (sendo o Estado, na grande maioria dos casos, uma destas partes), retirava da política social seu caráter meramente assistencialista. Por sua natureza meritocrática - faz jus a um certo benefício aquele que por sua inserção na estrutura ocupacional efetuou preteritamente a contribuição correspondente - o seguro social destituía a política social de estigma. Deslocando seu alvo principal da pobreza para o trabalho assalariado, a política social ganha papel pró-ativo no sistema: assegura direitos sociais aos que dele participam, hierarquiza o universo dos merecedores de tais direitos segundo as suas (dele) conveniências, e provê mecanismos de controle sobre os que dele se afastam.

A crise dos anos 1920, as transformações ocorridas no padrão de produção capitalista, a vitória do socialismo na URSS, a valorização do planejamento na própria teoria econômica, e duas guerras mundiais compõem o pano de fundo de um novo contexto, no qual emerge a terceira fase da política social no Ocidente

\footnotetext{
${ }^{13}$ Ver MERQUIOR, 1991; ASHFORD, 1986.

${ }^{14}$ Os problemas de maior urgência para os assalariados alemães, naquela oportunidade (inspeção das condições de trabalho, regulamentação da jornada de trabalho, fiscalização dos contratos de trabalho), não foram tocados. Bismarck compartilhava com os liberais (e com os empresários) a firme opinião de que qualquer interferência nos negócios privados seria nociva ao sistema. Reprimindo reivindicações mais vigorosas, por um lado, e, por outro, oferecendo concessões em termos de política social, infringiu uma derrota ao movimento sindical e consolidou o recém-unificado Reich (TAMPKE, 1981).
} 
desenvolvido. No plano da realidade, nessa fase, a idéia de seguro é substituída pela de seguridade social, a natureza da política passa a ser universalista e seu alvo, a cidadania. Sistemas públicos, estatais ou regulados pelo Estado se tornam os produtores de políticas destinadas a garantir amplos direitos sociais a todos os cidadãos, configurando o que se convencionou chamar Estados de bem-estar social.

No plano da reflexão, a institucionalização e a especialização das ciências sociais, conferindo a cada uma delas simultânea e diferenciadamente estatuto acadêmico e inserção profissional, tornam mais diversificadas as correntes de pensamento e mais diluídas as premissas teóricas sobre a questão social. No entanto, não é difícil encontrar em Keynes (particularmente em Essays in Persuasion), assim como em textos de Beveridge (anteriores ao relatório apresentado ao parlamento inglês em 1942) e de intelectuais fabianos, o núcleo de uma discussão que, desde o fim do século XIX, buscava conciliar, na teoria, justiça social e liberdade individual. Mais do que na ciência política, que surgia como campo do conhecimento, é entre autores doublés de pensadores (economistas políticos ou filósofos sociais) e militantes (liberais ou socialistas) que o papel do Estado naquela conciliação recebe atenção privilegiada. O exemplo das girafas que Keynes usa, em sua crítica à economia ortodoxa, vem seguido da constatação de que "sugerir à City de Londres uma ação social para o bem público é como discutir a Origem das Espécies com um bispo, sessenta anos atrás"15. Ao Estado caberia colocar em prática a proposição de que "a comunidade deve necessariamente pretender, conscientemente ou não, sua continuidade como comunidade: sua existência transcende a de qualquer um de seus membros; e os interesses de um indivíduo podem, muitas vezes, entrar em conflito com os do conjunto"16. Por sua vez, a comunidade passaria a ser entendida como conjunto de cidadãos - não mais apenas de indivíduos - aos quais deveriam ser garantidos direitos civis, políticos e sociais (MARSHALL, 1967) ${ }^{17}$. A incorporação da noção de cidadania positiva (ou substantiva) na reflexão é ilustrativa de uma nova percepção da questão social. As ameaças à integridade da sociedade não se resumem mais apenas à pobreza e/ou ao assalariamento. Vêm das desigualdades concretas; ao conceito ampliado de cidadania será reservada a função - no plano da reflexão como no da realidade - de conceder status de igualdade - no domínio público - a seres desiguais na esfera privada ${ }^{18}$.

Após a II guerra mundial, praticamente todos os países europeus desenvolvidos realizaram reformas em seus sistemas de proteção social. O marco reformista foi o relatório Beveridge transformado na Lei da Seguridade Social em 1946. A proposta estava fundamentada em dois princípios, identificados com a

\footnotetext{
${ }_{15}$ John M. Keynes, "O Fim do 'Laissez-Faire'... [1926], em SZMRECSÁNYI (1978, p.120). O exemplo das girafas está nas pp. 116-118. "Se levarmos a sério o bem-estar das girafas, não devemos menosprezar o sofrimento das de pescoços mais curtos, que morrem de fome, ou as folhas doces que caem no chão e são pisadas na luta, ou a superalimentação das de pescoços compridos, ou o mau-olhado de angústia ou cobiça agressiva que anuvia os semblantes suaves da multidão". O texto original foi incluído na edição de Essays in Persuasion, de 1931.

${ }^{16}$ Sidney Webb, "As Bases Históricas do Socialismo" (1889), em TEIXEIRA (2002). Os grifos não estão no original ${ }^{16}$ Sidney Webb, "As Bases Históricas do Socialismo" (1889), em TEIXEIRA (2002). Os gritos não estão no original
e visam sublinhar a visão do autor de comunidade como sociedade. Vale lembrar que Webb foi um dos fundadores da London School of Economics and Political Science, em 1895; ao mesmo tempo teve intensa atividade política. ${ }^{17}$ O texto de Marshall, "Cidadania e Classe Social", incluído no volume citado, é de 1949.

${ }^{18}$ Essa concepção está explicitamente formulada no citado texto de Marshall, embora ele tenha ficado conhecido apenas pelo enunciado da idéia de cidadania como conjunto ampliado de direitos.
} 
\{ Voz, Alívio e Oportunidade ou a Política Social de Arquimedes no Brasil - VIANNA, M.L.T.W. \}

nova concepção de proteção social. O princípio da unidade tinha por metas a unificação das múltiplas instâncias de gestão dos seguros sociais existentes e a homogeneização das prestações básicas. Universalidade, o outro princípio, dizia respeito à cobertura - todos os indivíduos - e ao escopo da proteção (todas as necessidades essenciais) ${ }^{19}$.

O contexto econômico no qual se edificaram os sistemas de bem-estar na Europa ocidental foi, de certo, favorável à ampliação dos direitos substantivos, que exigem não só normatividade como recursos para seu financiamento. No rastro da reconstrução pós-guerra e da maciça aplicação de recursos pelo Plano Marshall, o crescimento da produção, a industrialização em larga escala, o consumo de massa, asseguravam o pleno emprego e contribuíam para uma maior homogeneidade social. Mas é, sobretudo, na dimensão política da realidade que se explica o sucesso desta concepção de proteção social. As instituições de representação - os partidos políticos, os sistemas eleitorais, o Parlamento - se tornaram mais inclusivas; novos espaços de negociação surgiram (câmaras consultivas ou deliberativas formadas por representantes de trabalhadores, empresários, produtores agrícolas e técnicos governamentais para estabelecer diretrizes macroeconômicas); a social democracia, enfim, concretizou-se (OFFE, 1984, PRZEWORSKI, 1989). Por sua vez, a organização política dos atores sociais se fortaleceu. Identidades coletivas coesas, com alto poder de agregação e alta representatividade adotaram estratégias de concertação, ou seja, acordos, que permitiram aumentos substanciais na tributação (principalmente do capital) e provimento de benefícios generosos à maioria da população (WERNECK VIANNA, 1998 ${ }^{20}$.

A estrutura de benefícios que o Estado de bem-estar vai oferecer, variável de país para país, subentende, com efeito, a noção alargada dos riscos sociais, acima mencionada ${ }^{21}$. Para os indivíduos, ultrapassando os círculos danosos relacionados com a pobreza e com o assalariamento, mantêm-se os riscos do acidente de trabalho, cujo conceito incorpora o trajeto e as consequências, e da cessação temporária ou permanente da capacidade laborativa (assalariada ou não); reverte-se o eixo do risco da doença, privilegiando-se a saúde ${ }^{22}$; legitima-se o risco do desemprego e assume-se, também como social - isto é, involuntário, e portanto de responsabilidade

\footnotetext{
${ }^{19}$ Estes princípios influenciaram as reformas de outros países. Na Alemanha, por exemplo, orientaram o debate que precedeu a Carta Constitucional de Bonn, em 1949. Na França, inspiraram a proposta de lei enviada por De Gaulle à Assembléia Nacional solicitando a reorganização da seguridade social em 1947. Nos EUA, porém, tal influência foi praticamente nula; os debates sobre ampliação de direitos só vão ocorrer nos anos 1960 . Ver WERinfluência foi praticamente nula; os debates sobre ampliação de direitos só vão ocorrer nos anos 1960. Ver WER-
NECK VIANNA (1998).

${ }^{20} \mathrm{O}$ contexto descrito muda inteiramente a partir de fins dos anos 1970, quando se encerra o chamado círculo virtuoso do capitalismo. Embora abalada, a institucionalidade política do Estado de bem-estar manteve, contudo, seus traços fundamentais. Ver CONDÉ (2004).

${ }^{21} \mathrm{Na}$ literatura sobre Estados de bem-estar é recorrente a ênfase na variedade de arranjos, assim como o uso de classificaç̃es que permitem visualizar traços gerais. Mas é freqüente também a menção a uma concepcão européia, na qual a noção alargada dos riscos sociais tem como contrapartida um entendimento da cidadania associado a uma robusta estrutura de direitos coletivos. A concepção européia contrasta vivamente com a concepção americana de bem-estar social. Ver WERNECK VIANNA (1998, cap.2).

${ }_{22}$ Muitos países adotaram sistemas nacionais de saúde, universais e gratuitos. Nos que preservaram a fórmula dos seguros, como a Alemanha, os seguros-saúde, que passam a incluir outros segmentos sociais não enquadrados em categorias ocupacionais, substituíram os seguros-doença.
} 
da nação - o risco a que estão submetidas famílias numerosas com renda insuficiente para viver condignamente. Para a sociedade, mais que a pobreza, mais que a recusa à disciplina do assalariamento, reconhece-se como ameaça a não-integração. Como observa Esping-Andersen, o Welfare State construído no pós-guerra é, acima de tudo, um projeto de integração nacional ${ }^{23}$. A integração torna-se necessária do ponto de vista econômico: os indivíduos devem integrar-se no mundo da produção e do consumo de massa, sujeitando-se a desempenhar tarefas extremamente fragmentadas e repetitivas (como Carlitos, no filme de Chaplin, Tempos Modernos). Mas torna-se particularmente crucial no campo da política: a conformidade com as regras da democracia representativa deve compensar, substantivamente, para indivíduos que não são substantivamente iguais, o atrativo exercido pela alternativa socialista, então exitosa na consecução da justiça social.

A forte presença do Welfare State na Europa Ocidental talvez tenha tido um efeito inibidor sobre a formulação direta, no plano da reflexão, acerca dos fundamentos teóricos da conciliação entre justiça social e liberdade individual. Conciliação cujos supostos primordiais residem, cabe insistir, na percepção da questão social como desigualdade e na transmutação da desigualdade em ausência de substantividade da cidadania igualitária, e que foi operada, no plano da realidade, por tal arranjo institucional provedor de direitos sociais universais. Indiretamente, essa complexa combinação de premissas liberais, não-liberais e anti-liberais ultrapassou as fronteiras do velho mundo, vindo a manifestar-se em variadas abordagens sobre a questão social ${ }^{24}$.

O pensamento concorrente, porém, seguiu caminho inverso. Tornou-se mais rigoroso na elaboração de fundamentos teóricos para a refutação da capacidade de conciliação do Welfare State entre justiça social e liberdade individual. Hayek, provavelmente o mais nítido expoente do pensamento neoliberal, ou seja, do novo liberalismo, publica, em 1944, O Caminho da Servidão, no qual acusa o planejamento e o Estado previdenciário de levarem à tirania (MERQUIOR, 1991). Friedman, Nozik e outros darão sequência à construção. Buchanan e Rawls oferecerão variantes dela. Em síntese, o jogo de soma positiva implícito na hipótese de conciliação entre justiça social e liberdade individual é, enquanto premissa, rechaçado: a justiça social operada pelo Welfare State destrói a liberdade individual. Como rechaçada é, também, a compreensão da questão social que lhe dá suporte: as ameaças à ordem social não provêm das desigualdades, inerentes ao universo humano, e sim das restrições à realização da individualidade, meta igualmente inerente ao universo humano. Aqui está, ou deveria mais assumidamente estar, o eixo do debate teórico atual concernente às políticas sociais e às suas estratégias universalistas ou focalizadas - de concretização. Não é o que parece acontecer no mundo e não é, certamente, o que acontece no Brasil.

\footnotetext{
${ }^{23}$ ESPING-ANDERSEN (1995)

${ }^{24}$ Poderiam ser analisadas, por exemplo, as abordagens produzidas no âmbito da América Latina, como as da CEPAL ou as do ISEB, nos anos 1950 e 1960; ou as abordagens da teoria da modernização, elaboradas sobretudo por cientistas sociais americanos nas décadas de 1960 e 1970 do século XX.
} 
Conforme sobejamente já apontado, no Brasil, a inspiração do movimento de ideias que, convergindo com outros vetores, culminou na Constituição Federal de 1988, veio claramente da concepção europeia de Estado de bem-estar social. A Carta estabelece um sistema universal de seguridade social, universal e integrado, o que tem implicações simbólicas e práticas. Simplificadamente, as implicações simbólicas podem ser resumidas na vinculação da proteção social ao conceito marshalliano de cidadania; as implicações práticas decorrem do princípio do financiamento compartilhado de benefícios contributivos e não contributivos ${ }^{25}$.

Essa concepção, como também se sabe, não chegou a se materializar. Nos anos 1980, quando ela integrava a pauta de demandas na luta pela democratização no país, parecia tornar-se dominante no resto do mundo a nova concepção liberal, ainda que essa dominância tenha sido mais alardeada do que praticada. A partir dos anos 1990, entretanto, e especialmente a partir da segunda metade da década final do século XX, uma novíssima concepção liberal vai ocupar espaços cada vez mais sólidos e amplos. Embora não constitua nenhuma originalidade brasileira, o exemplo nacional é bastante esclarecedor do conteúdo da mesma, bem como das premissas que a informam.

Entre parênteses, não custa lembrar que é nos anos 1990 que a legislação regulamentadora dos preceitos constitucionais começa a ser produzida no Brasil. Desde então, inicia-se concomitantemente o desmonte institucional, orçamentário e conceitual da seguridade social. Cada uma das áreas previstas para compor organicamente o sistema - saúde, previdência e assistência social - encastela-se em seu próprio ministério. Cada uma das áreas terá suas fontes vinculadas de financiamento: as variadas receitas constitucionalmente estabelecidas em conjunto para a seguridade serão setorializadas e ao mesmo tempo centralizadas num órgão externo à seguridade, o Tesouro. O princípio da integração foi, assim, explicitamente derrogado e, no rastro do discurso oficial de que o mundo havia mudado, o abandono do princípio da universalidade, embora jamais explicitado, tomou forma na adoção enaltecida de práticas inovadoras. A expressão programas sociais passou a figurar como indicativa, na retórica oficial, de uma renovação da ideia de proteção social, desembaraçando-a da pesada carga contida no conceito de sistema.

Em que consiste a inovação e porque se configura como expressão de uma novíssima concepção liberal? A resposta mais abrangente é: a inovação consiste em resgatar a possibilidade de conciliação entre justiça social e liberdade individual sem descartar a premissa liberal do primado da liberdade sobre a igualdade, ou seja, reiterando como meta a realização da individualidade. Políticas sociais inovadoras são aquelas que "introduzem mudanças significativas em relação a

\footnotetext{
${ }^{25}$ Sobre o sistema de seguridade social implantado pela Constituição Federal de 1988 no Brasil, ver TEIXEIRA (1990), WERNECK VIANNA (1998), GENTIL (2006), entre outros.

${ }^{26}$ Coleção 20 Experiências de Gestão Pública e Cidadania, Ciclo de Premiação 2005, apresentação (os grifos não estão no original). Ver HTTP://inovando.fgvsp.br. Trata-se de um programa mantido pela Fundação Getúlio Vargas em conjunto com a Fundação Ford e apoio do BNDES no período 1996 - 2005, que selecionava os vinte melhores projetos de políticas públicas entre centenas que foram apresentados por estados e municípios, tendo, em sua maioria, o enfrentamento da questão social como propósito. O banco de dados continua disponível.
} 
práticas anteriores, têm impacto positivo sobre a qualidade de vida das comunidades; ampliam ou consolidam o diálogo entre a sociedade civil e os agentes públicos" ${ }^{\prime 26}$. Ou ainda, as que estão "centradas na cidadania ativa", buscam envolver "os cidadãos na produção e/ou gerenciamento dos serviços públicos", estimulam "a co-responsabilização dos usuários" e se deslocam "do âmbito estatal para o cidadão" 27.

Respostas mais precisas exigiriam investigação de maior fôlego do que a aqui exposta. Todavia, como o intuito é jogar lenha na fogueira das discussões, um rápido olhar (medianamente atento) sobre certos traços da concepção de política social predominante hoje no Brasil, destacados pela farta literatura produzida no país sobre o tema, ajuda a dar consistência ao argumento.

Políticas sociais, de âmbito municipal, estadual ou federal tornaram-se objeto de dissertações e teses de pós-graduação, de artigos em revistas especializadas, de vasta produção, enfim, nas várias áreas das ciências sociais e dos chamados campos multidisciplinares do conhecimento. Paralelamente, a questão social passou a figurar como ponto de convergência de expressiva quantidade de análises acadêmicas. $\mathrm{Na}$ maior parte dos trabalhos, contudo, a tendência que sobressai, tanto nos que versam sobre políticas sociais (subentendendo uma dada visão da questão social) quanto nos que examinam a questão social (subentendendo uma dada visão de política social), é a de superestimar a descrição empírica (e os métodos para realizála) em detrimento da elaboração teórica. A ciência social assume, assim, um caráter de ciência-fotografia ${ }^{28}$.

Essa ciência-fotografia não abdica de rigor; ao contrário, a fotografia é de alta definição. Diagnósticos, estatísticas, indicadores, modelos desvendam a realidade. Os múltiplos aspectos e dimensões da questão social - renda, educação, saúde, religião, condições de moradia de diferentes segmentos da população, etc. - são observados. A empiria, sofisticadamente tratada, possibilita, destarte, inferir as intervenções adequadas e avaliar seus resultados.

No entanto, por mais útil e meritório que seja o esforço investigativo da ciência social que se pratica hoje no Brasil em torno da questão social e de seu enfrentamento, não logra ofuscar uma congênita insuficiência. A despeito de tornar a realidade mais visível, porque quantificada e mensurada, bem como as políticas destinadas a operar sobre ela passíveis de avaliação a partir de instrumentos afinados, destitui de validade e importância as interpretações teóricas (tentativas e controversas, por suposto). Vão para o ostracismo as polêmicas em torno dos fundamentos e da capacidade explicativa de concepções rivais, que sempre mobilizaram os pensadores.

É como conseqüência dessa tendência empiricista que emerge o consenso acima mencionado. A concepção de política social que hoje prevalece se apresenta como a política social, no pressuposto implícito de que a realidade (fielmente retratada pela tecnologia disponível) assim o demonstra. Mas a realidade assim o

\footnotetext{
${ }^{27}$ JACOBI (2002). "Estas experiências que denominamos inovadoras fortalecem a capacidade de crítica e de interveniência dos setores de baixa renda através de um processo pedagógico e informativo de base relacional, assim como a capacidade de multiplicação e aproveitamento do potencial dos cidadãos no processo decisório dentro de uma lógica não cooptativa".
}

${ }^{28}$ Ver WERNECK VIANNA (2008). 
\{ Voz, Alívio e Oportunidade ou a Política Social de Arquimedes no Brasil - VIANNA, M.L.T.W. \}

demonstra porque há uma (também pressuposta) unanimidade a respeito da natureza da questão social uma vez que essa natureza é, de igual modo, revelada pela realidade. Dispensáveis passam a ser, portanto, as fundamentações teóricas, e supérfluas as discussões acadêmicas sobre elas. O mito do "fim" - da história, da ideologia se aplicaria aos antagonismos na esfera da teoria econômica, social, política, etc. Política social é política para os pobres. Para os pobres, não para a pobreza. Para os pobres, indivíduos cuja individualidade não se realiza em função de restrições que podem - e devem - ser amenizadas.

Premissas teóricas (e repetindo, mais uma vez, por suposto controversas), entretanto, fundamentam tal concepção predominante de política social, bem como a concepção da questão social que lhe é subjacente. Simplificadamente, e sem nenhuma pretensão de esgotar a lista, algumas dessas premissas, bem como aquelas que as refutam, transparecem com nitidez quando se perscruta as principais proposições da concepção em tela.

A primeira consiste em reduzir a questão social à pobreza. Ora, como observa Castel, a "questão social é uma aporia fundamental sobre a qual uma sociedade experimenta o enigma de sua coesão e tenta conjurar o risco de sua fratura" (1998, p. 30). Pode ser a pobreza como pode ser o conflito de classes. Ou seja, como sugerido atrás, adquire formas diversas, no plano da realidade, em diferentes condições históricas, sistêmicas, etc.; e demarca-se, no plano da reflexão, sob a égide da adoção de uma dada vertente de análise. Do entendimento reducionista de que a questão social é a pobreza decorre a acepção de que política social tem por função proteger os pobres, o que está longe de ser consensual. Para Polanyi, ratificado por Castel - as ações governamentais de cunho social (voltadas ou não apenas para os pobres) têm historicamente por função proteger a sociedade como um todo dos riscos que a expansão do mercado acarreta, em particular das desigualdades que, no limite, ameaçam a própria integridade do tecido social ${ }^{29}$. A premissa de que a questão social está na pobreza, embute também o viés de que política social, como política para os pobres e portanto de natureza assistencial, se associa à bondade. Tal compreensão, que obviamente se contrapõe às de Polanyi e Castel - e que contraria todos os clássicos da teoria política desde Maquiavel -, possibilita a seus seguidores desconsiderar como sociais outras políticas, como transportes, saneamento, de certo modo a saúde, e, muito especialmente, a previdência social.

Uma segunda proposição se insinua a partir da anterior: a definição de pobreza como uma situação em que indivíduos se encontram por falta de certos dotes ou assets que uma vez adquiridos os habilitam a pular a linha da pobreza e, assim, poder almejar o acesso à meta de realização da individualidade ${ }^{30}$. Escolaridade, auto-cuidado com a saúde, saber lidar com a renda, constituem os ativos primordiais que equalizam os indivíduos. Definida a questão social como pobreza e pobreza como carências individuais - definição que teorias rivais refutariam, apondo o papel

\footnotetext{
29 POLANYI (1980).Ver, sobretudo, os capítulos 7, 8 e 9

${ }^{30}$ Essa definição de pobreza está claramente enunciada no Relatório PNUD 1990. Na literatura brasileira, ver PAES e BARROS (2001), ROCHA (2003). Excelentes e minuciosas análises dessa concepção (e dos fundamentos teóricos que as embasam) estão em UGÁ (2008) e MAURIEL (2008). O termo assets está em BANCO MUNDIAL (2000).
} 
das estruturas econômicas, sociais e políticas -, descobre-se mais um preceito essencial: políticas sociais de natureza coletiva, universais, não são as únicas nem as mais eficazes para lidar com a questão social. Quando dominam o cenário da proteção social tendem a desequilibrar o orçamento fiscal, desperdiçar recursos, penalizar investimentos e a não alcançar devidamente os pobres. Devem, portanto, se restringir àquelas que propiciam igualdade de oportunidades para o exercício da liberdade, como educação fundamental e atenção básica à saúde e servir como braço auxiliar de ações inovadoras, quais sejam, as que se dirigem a indivíduos, a grupos específicos, a comunidades (pobres, naturalmente), que merecem ser tratados de modo diverso em respeito às diferenças que guardam entre si.

O conceito de inovação aplicado à política social ilumina a terceira proposição. Inovadora é a política social capaz de introduzir "mudanças significativas em relação a práticas anteriores" e assim diferenciar-se do assistencialismo tradicional, porque essas são exigências incontestáveis da atual conjuntura ${ }^{31}$. Tal premissa se desdobra na assertiva de que as "novas" políticas (assistenciais) para os pobres, ao exigirem condicionalidades, funcionam como mecanismos de empoderamento, isto é, ensejam a aquisição dos dotes necessários ao exercício das escolhas. Mediante a "promoção do alívio imediato da pobreza (...), o reforço ao exercício de direitos sociais básicos nas áreas de saúde e educação (...), o que contribui para que as famílias consigam romper o ciclo da pobreza entre gerações ${ }^{\prime 32}$, indivíduos se tornam capazes de superar a situação de vulnerabilidade. Induzidos a freqüentar cursos nos quais "aprendem a pescar" - e a usar o microcrédito para comprar o anzol -, ganham auto-estima ${ }^{33}$; instados a participar (de conselhos e atividades comunitárias), auferem os dividendos do capital social ${ }^{34}$.

4. Vox populi como voz dos pobres: a cereja do bolo da nova política social

A Constituição Federal de 1988 também consagrou a prática participativa como inerente à gestão democrática das políticas sociais. O famoso artigo 194 estabelece, entre os objetivos com base nos quais "compete ao poder público organizar a seguridade social", a participação da comunidade. No que concerne aos direitos relativos à saúde e à assistência, tratados respectivamente nas seções II e IV da Carta, a participação é reiterada, como "participação da comunidade", no caso da saúde, e, no da assistência social, como "participação da população, por meio de organizações representativas, na formulação das políticas e no controle das ações em todos os níveis".

\footnotetext{
31 A atribuição de inexorabilidade às transformações em curso na realidade é componente relevante tanto da nova quanto da novíssima concepção de questão social.

${ }^{32}$ Ver o portal eletrônico do Ministério do Desenvolvimento Social e Combate à Fome.

${ }^{33}$ Microcrédito, cursos de qualificação para o exercício do pequeno negócio e outros incentivos ao empreendedorismo passaram a ser, simultaneamente aos programas de transferências de rendas, o núcleo da nova política social. Ver WERNECK VIANNA (2008).

${ }^{34}$ O Relatório sobre Desenvolvimento Mundial de 2000/2001 caracteriza a pobreza a partir de três eixos: i) falta de renda e recursos (assets) para atender necessidades básicas, incluindo educação e saúde; ii) falta de voz e de poder nas instituições estatais e na sociedade; iii) vulnerabilidade a choques adversos e exposição a riscos, combinados com uma incapacidade de enfrentá-los. Ver BANCO MUNDIAL (2000) e UGÁ (2008).
} 
\} Voz, Alívio e Oportunidade ou a Política Social de Arquimedes no Brasil - VIANNA, M.L.T.W. \}

O modelo participativo foi institucionalizado, nessas áreas, com as leis 8.142, de 1990, e 8.742, de 1993. A primeira dispõe "sobre a participação da comunidade na gestão do Sistema Único de Saúde e sobre as transferências intergovernamentais de recursos financeiros e dá outras providências", bem como institui, "sem prejuízo das funções do Poder Legislativo", as instâncias colegiadas de participação, conferências e conselhos de saúde, atribuindo-lhes papéis deliberativos e fiscalizadores. A segunda, a Lei Orgânica da Assistência Social (LOAS), reafirma como diretriz o ditame constitucional da participação da população e estipula as atribuições dos conselhos municipais e estaduais: aos conselhos municipais cabem, inclusive, as funções de reconhecer - mediante registro -, e fiscalizar as entidades e organizações não-governamentais de assistência social. O SUAS (Sistema Único de Assistência Social), nos moldes do SUS, passou a configurar a "forma de operacionalização da LOAS, que viabiliza o sistema descentralizado e participativo e sua regulação em todo o território nacional"..$^{35}$

Participação - social, da população, da comunidade -, controle social (leiase pela e não da sociedade), gestão participativa. Saudado como inovação, o modelo participativo, constitucionalizado na saúde e na assistência social, expandiu-se, associado à descentralização, para outras políticas públicas ${ }^{36}$. O cumprimento dos papéis, atribuições e funções delegados a tais fóruns tem sido examinado, como ocorre com as políticas sociais de "novo tipo", por uma também pujante literatura, literatura que, no caso, busca principalmente avaliar ou discutir a efetividade das instâncias criadas para dar voz à chamada sociedade civil, em especial os conselhos municipais (de saúde, assistência social e demais).

Para o cientista social, contudo, mais uma vez cabe ressaltar que não basta diagnosticar a realidade, ou seja, a efetividade dos conselhos ou de outras modalidades de participação. Como esferas simultaneamente de representação das partes envolvidas com a as políticas setoriai ${ }^{37}$, e de exercício direto da cidadania pela população ${ }^{38}$, a prática participativa suscita indagações que precedem a análise de sua efetividade. Que processos devem ser considerados como participatórios: a escolha de representantes (e por que vias) ou a expressão direta de demandas (individuais ou coletivas)? Que dimensões da vida social devem ser destacadas para que se identifique a ação participativa? Enfim, como definir participação no plano da reflexão?

\footnotetext{
35 Portal do MDS, visitado em 22/04/2009. O SUAS foi a principal deliberação da IVa Conferência Nacional de Assistência Social, realizada em Brasília, em 2003. Tornou-se realidade a partir de sua aprovação pelo Conselho Nacional de Assistência Social em julho de 2005.

${ }^{36}$ AZEVEDO \& ANASTASIA (2002) mencionam a existência, em 2000, de 125 conselhos setoriais na Região Metropolitana de Belo Horizonte e 75 na Região Metropolitana do Rio de Janeiro.

${ }^{37}$ No caso da saúde, para receberem "os recursos, de que trata o art. $3^{\circ}$ desta lei, os Municípios, os Estados e o Distrito Federal deverão contar com: (I) Fundo de Saúde; (II) Conselho de Saúde, com composição paritária de acordo com o decreto $\mathrm{n}^{\circ} 99.438$ de 7 de agosto de 1990.." (Lei 8.142). O citado decreto estabelece a representação do governo, dos prestadores de servicco, profissionais de saúde e usuários para atuar na formulação de sentação do governo, dos prestadores de serviço, profissionais de saúde e usuarios para
estratégias e no controle da execução da política de saúde na instância correspondente.

estratégias e no controle da execução da política de saúde na instância correspondente.
${ }_{38}$ (...) "O grande desafio da Gestão Participativa é consolidar práticas e experiências inovadoras que consigam incluir a comunidade na formulação das políticas, respeitando seus próprios recursos e saberes, apostando na capacitação e formação para o fortalecimento político da população, para que a mesma alcance autonomia para exercer plenamente seu dever de cidadania" (VII Congresso Nacional da Rede Unida, Oficina 47 - Gestão Participativa e Apoio ao Controle Social, Curitiba, julho de 2006).
} 
Definições de participação que ultrapassem a óbvia perspectiva da semântica vernacular - tomar parte -, requerem a identificação de diferentes quadros de fundamentação teórica, quadros esses formulados em também diferentes contextos históricos. Ou seja, seguindo o raciocínio antes enunciado, é pertinente afirmar que não há, a priori, um marco teórico no qual incluir o conceito de participação. Esforços realizados por pesquisadores em áreas específicas no sentido de situar teoricamente o conceito parecem confirmar essa afirmativa.

CORTES (1996-a) procura mostrar como a questão da participação é tratada, de modo diferenciado, por "praticamente todas as correntes de pensamento político e sociológico". Seguindo a tendência taxonomista da ciência social americana, a autora apresenta as "cinco correntes de pensamento que analisam o papel do Estado em sociedades modernas: o pluralismo, a teoria das elites, a nova direita, o marxismo e o neopluralismo" ${ }^{\prime 39}$. A revisão de CORTES (1996-a) sugere a impossibilidade de se entender o sentido do conceito de participação sem inseri-lo numa dada corrente teórica. Entretanto, a autora enfatiza mais a dimensão propositiva das correntes examinadas do que os fundamentos que oferecem para a elucidação do conceito de participação.

Em primeiro lugar, excluindo-se os pluralistas tradicionais, todas as demais correntes criticam o caráter pouco democrático das instituições políticas das democracias liberais. Em segundo lugar, com exceção da teoria das elites e de parte dos neopluralistas e dos marxistas, as outras teorias posicionam-se em favor da descentralização da administração pública. Os autores da teoria das elites não são favoráveis à descentralização, porque não acreditam que ela possa afetar a natureza essencialmente não democrática das relações de poder. Já estes neopluralistas e marxistas preocupam-se mais em defender a promoção de políticas igualitárias do que com a forma territorial dos governos (CORTES, 1996-a, p. 75; grifos acrescidos).

Gascón; Tamargo \& Carles (2005) também reconhecem que participação é um conceito "através do qual se podem perceber as transformações nos contextos históricos, econômicos, políticos e sociais nos quais a noção de participação foi assumindo distintos matizes em relação à amplitude ou restrição de seus alcances e implicações". No entanto, admitem a existência de um "absoluto consenso" em relação a uma definição genérica segundo a qual participação seria "a capacidade que têm os indivíduos de intervir na tomada de decisões em todos aqueles aspectos de sua vida cotidiana que os afetam e envolvem".

Além de reforçarem a ideia de que o conceito de participação se dilui em teorias diversas, os dois textos citados compartilham uma visão que importa sublinhar: a de que a discussão sobre o tema é nova nas agendas pública e acadêmica. Embora Gascón; Tamargo \& Carles (2005) tenham por intenção analisar o uso do

${ }^{39}$ Essa classificação, embora muito usada, merece discussão. Ver: WERNECK VIANNA (2009). 
\} Voz, Alívio e Opotunidade ou a Política Social de Arquimedes no Brasil - VIANNA, M.L.T.W. \}

conceito na América Latina, a revisão bibliográfica que efetuam permite ampliar o alcance da hipótese.

Entre o final dos anos sessenta e primeira metade dos anos setenta, a literatura especializada internacional empreendeu uma intensa discussão sobre o conceito de participação e de participante, referindo-se a processos participatórios criados em instituições e em projetos de governos ou de agências de desenvolvimento (CORTES 1996-a).

A participação como conceito tem sido objeto de debate teórico e político desde a segunda metade do século XX, primordialmente no campo das ciências sociais, [no campo] do desenvolvimento social e [no das] políticas sociais destinadas a reduzir as condições de iniqüidade, pobreza e exclusão social (GASCÓN, TAMARGO \& CARLES, 2005).

Essas citações são preciosas para introduzir a discussão sobre certos aspectos singulares dessa dimensão da nova política social que é a participação, bem como para esmiuçar os laços que tem com a tal novíssima concepção liberal indicada acima. Três objeções, tratadas a seguir, podem ser adiantadas: a) o conceito de participação tem a idade da teoria social moderna - algo em torno de quatro séculos -, como participação na polis e, pois, participação política; b) a novidade introduzida pelo "debate teórico e político" no século XX consistiu em substituir o adjetivo política pelo adjetivo social, passando-se a empregar como sinônimas as expressões participação social e participação política; c) o uso clássico do conceito de participação como participação política difere, porém, do uso novo do conceito de participação como participação social porque o primeiro se refere à participação de todos os membros da polis - condição de direito (e de dever) universal -, enquanto que o segundo se aplica a segmentos específicos da população: os pobres, os excluídos, as minorias.

O tema da participação emerge com os contratualistas. Em particular na obra de Thomas Hobbes, Leviatã, na qual a criação da sociedade, política por excelência, se deve ao pacto que todos os indivíduos, naturalmente iguais, racionais e possessivos, fazem entre si. A polis, a commonwealth, é uma invenção dos seres humanos, de todos os seres humanos que habitam um território delimitado. Todos participam da criação do Estado e por isso são não só legítima e igualmente partes da polis como legítima e igualmente subordinados às regras que emanam do Estado. A obediência civil de todos, legítima porque todos tomaram parte na sua invenção, oferece a segurança necessária para que os indivíduos se dediquem, desigualmente, a seus labores privados ${ }^{40}$.

\footnotetext{
${ }^{40}$ Hobbes, Leviatã, [1651], Livro II, cap. XVII, Coleção Os Pensadores, São Paulo, Abril Cultural, 1974.
} 
A lógica da distinção entre uma esfera pública, inventada por todos e na qual todos são igualmente cidadãos, e uma esfera privada, domínio dos diferentes interesses que os indivíduos proprietários de si mesmos portam, se torna mais evidente nas formulações de John Locke, sobretudo nas que tece no Segundo Tratado de Governo. Os indivíduos, livres e iguais por natureza, criam, por acordo, a sociedade política ou civil, uma invenção humana inteiramente diversa da "sociedade conjugal" ou de qualquer outra forma de interação social que homens e mulheres naturalmente realizam ${ }^{41}$. O Estado nacional é o artifício construído pelos indivíduos para concretizar o descolamento entre a esfera da igualdade (todos são membros da sociedade política) e o mundo da liberdade (onde cada um goza, a seu modo, o direito natural à propriedade).

Essa diferenciação público-privado vai fundamentar as reflexões posteriores sobre os temas da participação e da cidadania. O ponto a salientar (e que mereceria aprofundamento aqui inviável) é a natureza política e igualitária que reveste ambas as noções em seu tratamento originário. Participar é tomar parte na criação da própria polis e, portanto, ser parte, em condições de igualdade (formal, não substantiva), da mesma. Ser parte se confunde com ser cidadão. O pensamento chamado liberal vai gradativamente distinguir, também, as esferas da participação e do exercício do poder, que passarão a ser relacionadas por intermédio da representação. A proposição da separação de poderes, na obra de Locke e depois na de Montesquieu, reforça a distinção ${ }^{42}$.

Mas é na obra de Stuart Mill (mais uma vez Stuart Mill), Considerações sobre o Governo Representativo, que essas questões, bem como a relação entre elas, ganha notória visibilidade. Argumentador efusivo em prol da democracia representativa e ardoroso defensor da fórmula "cada um, um voto" (inclusive para as mulheres), enuncia as razões que fazem do governo representativo a forma ideal de governo ${ }^{43}$. Para Balbachevsky (1989), "a obra de Mill pode ser tomada como um compromisso entre o pensamento liberal e os ideais democráticos do século XIX". O fundamento desse compromisso estaria no "reconhecimento de que a participação política não é e não pode ser encarada como um privilégio de poucos". A preocupação de Mill em dotar o Estado liberal de mecanismos capazes de institucionalizar essa participação ampliada, recorrente nos vários artigos que publicou (Macpherson, 1977), se ancorava na "aceitação de que, nas condições modernas, o trato da coisa pública diz respeito a todos" (Balbachevsky,1989).

Participação é, assim, um conceito que vai, tanto quanto o de cidadania, se abrigar, a partir do século XIX, sob as teorias da democracia liberal, ou sob os diferentes "modelos" de democracia, como mostra Macpherson em suas análises das variadas concepções de governo democrático postuladas nos séculos XIX e XX

\footnotetext{
${ }^{41}$ Locke, op. cit., cap. I.

${ }^{42}$ Não custa lembrar que o pacto imaginado por Locke, bem diverso daquele que Hobbes formula, é renovável, e a renovação se substantiva na escolha de "representantes" para o exercício do Poder Legislativo.

${ }^{43}$ Freio do despotismo, garantia de que "cada um é o único guardião seguro de seus próprios direitos e interesses", ${ }^{43}$ Freio do despotismo, garantia de que "cada um é o único guardião seguro de
e, principalmente, força impulsionadora do desenvolvimento individual.

${ }_{44} \mathrm{~A}$ inflexão que Marx imprime no pensamento ocidental, deslocando o eixo da participação política da esfera institucional para o campo da ação revolucionária, extremamente relevante para a composição de um painel das reflexões sobre o tema, não é abordado no presente texto pelas razões apontadas acima: trata-se de um texto preliminar com pretensões a amadurecimento e expansão posteriores.
} 
\} Voz, Alívio e Oportunidade ou a Política Social de Arquimedes no Brasil - VIANNA, M.L.T.W. \}

$(1965,1977)$. Vai ainda se traduzir prioritariamente como voto nos entes que representam a sociedade no interior do Estado e sempre como direito universal ou que demanda universalização -, de tomar parte nas decisões que afetam o coletivo, vale dizer, como participação política ${ }^{44}$.

No século XX, a variedade de correntes de pensamento que se instala no campo das ciências sociais não impede que o conceito de participação preserve sua conotação política. Seja nas inúmeras formulações desencantadas que descrevem a impotência do cidadão para decidir a respeito de assuntos públicos e sua diluição nas malhas da impessoalidade e da multidão ${ }^{45}$; seja na versão gramsciana do marxismo que entende a militância revolucionária sob formas diversas, dependendo das condições em que a hegemonia da classe dominante se exerce; seja na visão pragmática da democracia elaborada por Dahl (DAHL,1970), a conotação política da participação se mantém. O conceito de participação tem um percurso, nas ciências sociais, marcadamente ligado às teorizações sobre a democracia, com o que, mais uma vez, revela seus traços essenciais: é um dote (trasladado em direito ou em dever) universal que se exerce na esfera pública, prioritariamente através do voto creditado às instâncias de representação política. Mas mesmo nas concepções que se afastam ou não enfatizam a via da representação para a realização da democracia, o princípio da universalidade se revela recorrente. Tanto quanto se revela precípua a dimensão política da ação participativa.

Rousseau talvez seja o mais emblemático dos clássicos no que concerne ao tema da participação. Tido como avesso ao formato representativo do sistema político - o que, no contexto histórico em que viveu, não seria de estranhar -, entrou para a história do pensamento político como o grande teórico moderno da democracia direta. A democracia (ou a comunidade política justa e legítima) para Rousseau exige participação. Não apenas a participação de todos na sua criação, mas a reiteração permanente da vontade geral que igualmente emerge do ato fundante. Rousseau subordina a representação parlamentar (como mecanismo já então consagrado para reduzir o absolutismo monárquico), tanto quanto o aparato administrativo do Estado, à soberania do povo. A cidadania, como a face pública do indivíduo, e o poder soberano, como atributo dos cidadãos (e só deles), constituem os fundamentos para repensar os papéis da representação e da participação.

Participação - política e igualitária -, e não somente mediante o voto, é o instrumento de poder que o povo possui. Se dele abdica, torna-se escravo e joga o Estado (a pátria, como Rousseau várias vezes designa o ente coletivo) na ruína. O ceticismo de Rousseau quanto a possíveis transformações da sociedade européia no século XVIII não tolhe sua retórica de utópico moderno, conclamando o povo a participar ${ }^{46}$. Na utopia rousseauniana está o princípio republicano da virtude cívica, que redimensiona a noção de participação política igualitária, transmutando o voto de cada um em voz de todos os cidadãos.

\footnotetext{
${ }^{45}$ Os autores da chamada "teoria elitista" (Pareto, Mosca, Michels), Freud, Shumpeter e outros. Ver LESSA (1997).

46 "O povo reunido - dir-se-á - que quimera! Hoje é uma quimera, mas não o foi há dois mil anos. Os homens mudaram de natureza?" (Contrato, Livro III, cap. XII).
} 
Donzelot \& Epstein (2006) recorrem justamente à força do ideário republicano de inspiração rousseauniana na França para explicar as baixas taxas de participação da população francesa em projetos recentes de políticas públicas. Os autores examinaram a implementação de programas de restauração urbana em quatro cidades francesas, interrogando os atores encarregados das operações de demolição e reconstrução, com o intuito de recolher elementos para classificar a participação da população, prevista nas experiências. Utilizando a escala de Sherry Arnstein, uma metodologia criada em 1969, nos Estados Unidos, para medir "participação"47, concluem que em nenhuma das quatro experiências levadas a cabo na França a participação ultrapassa o segundo nível da escala de Arnstein (participação simbólica). Apresentam, em seguida, experiências participativas de remodelação urbana colocadas em prática nos Estados Unidos e na Grã-Bretanha que evidenciam a concretização do "poder efetivo dos cidadãos" (o nível 3 da escala de Arnstein). Donzelot \& Epstein (2006) explicam que "na França [a participação é] um exercício mais encantatório do que efetivo, sendo que, nos países anglo-saxões, ela indica um imperativo pragmático" porque, na França, a noção que norteia a ação pública reside no conceito de interesse geral, ao passo que os anglo-saxões têm como referência o bem-comum.

O interesse geral, seguem os autores, constitui uma espécie de substituto contemporâneo do conceito rousseauniano de vontade geral. A "participação" é pouco efetiva na França pois os indivíduos que se dispõem a participar pontualmente de programas sociais (mas não se interessam em participar das esferas políticas estabelecidas) são percebidos e denunciados como defensores de seus interesses privados, em contraposição ao interesse geral encarnado pelos poderes públicos. O conceito de participação, todavia, "continua sendo cultuado pelos franceses, porque remete ao sonho de obter uma confirmação unânime da decisão política pelo cidadão" que, ao participar, abandona seus interesses privados agindo conforme a "verdadeira legitimidade de uma vontade geral de facto" ${ }^{48}$.

Bem-comum (a commonwealth de Hobbes) é um conceito que se distingue do interesse geral, para Donzelot \& Epstein, em dois pontos: a) o bem-comum, ao invés de se opor aos interesses particulares, procura uni-los, "visa estabelecer um consenso, um critério de acordo"; b) a noção de bem-comum não envolve nenhuma intenção de alcançar um plano de igualdade real entre os atores sociais; ao contrário, nela está implícito o reconhecimento de que há diferenças substantivas entre aqueles que têm os meios de decidir (o poder, o dinheiro) e aqueles que são afetados pela ação projetada (os stakeholders); entre eles haverá apenas um acordo temporário. Os autores terminam o artigo afirmando que "os franceses buscam na participação muito mais uma legitimação da decisão do que uma mobilização pela ação". A

\footnotetext{
${ }^{47}$ Arnstein elaborou uma hierarquia de práticas participativas, distinguindo três níveis e oito graus possíveis na escala de participação. No nível mais baixo (nível 1) não há participação, há manipulação ou terapia (a participação visaria apenas obter apoio do público, mediante publicidade). O segundo nível é de cooperação simbólica: os "participantes" são informados, consultados ou "apaziguados". O nível 3 representa "poder efetivo dos cidadãos", mediante parceria, delegação de poderes e, ponto culminante, controle cidadão.

${ }^{48}$ Donzelot \& Epstein, op. cit.. Julia Polessa, da equipe do LEPS, fez a tradução, bem como um excelente resumo, desse texto.
} 
\{ Voz, Alívio e Oportunidade ou a Política Social de Arquimedes no Brasil - VIANNA, M.L.T.W. \}

democracia participativa, na França, tem o sentido de associar os cidadãos à tomada de decisões, "tendo como pano de fundo a tradição rousseauniana do Contrato Social".

Esse tipo de participação que os franceses rejeitam, segundo Donzelot \& Epstein (2006), e que encontra recepção favorável entre ingleses e americanos, não é exatamente a participação tal como a ciência social - de Hobbes a Dahl, pelo menos - compreendeu. Não é mais o conceito que, utilizado de modo variado pelas variadas teorias formuladas desde o século XVI, guardou como marca comum de seu emprego a designação de um processo político e universal.

A novidade da discussão atual sobre participação consiste no entendimento de que participar é intervir na tomada de decisões "em todos aqueles aspectos da vida cotidiana" que afetam os indivíduos (Gascón, Tamargo \& Carles, 2005). Ou seja, não mais apenas intervir na dimensão pública da política, mas, sobretudo, intervir nas decisões que concernem à vida privada dos indivíduos: onde morar, como preservar a saúde, em que ofício trabalhar, etc. Ora, não são todos os indivíduos que precisam ter alavancada sua capacidade de intervir nas decisões que afetam sua vida cotidiana. Todos podem escolher representantes para o Parlamento, votar para a Presidência da República ou manifestar sua vontade em referendos ou plebiscitos. Nem todos podem, igualitariamente, preferir tal ou qual bairro para moradia, optar por determinado tipo de tratamento médico ou decidir seu futuro profissional. A participação social é entendida como um mecanismo destinado a incluir segmentos que, na esfera da sociedade (ou do mercado), em sua vida cotidiana, se encontram excluídos de qualquer oportunidade de escolha ${ }^{49}$.

Cortes (1996-b) detecta, no plano da realidade, dois fatores explicativos da "criação de novas formas de envolvimento dos cidadãos no processo político". O primeiro seria a "tangível desilusão com as instituições políticas verificada em várias democracias liberais ocidentais, desde o final dos anos sessenta" ${ }^{\prime 50}$. Por outro lado, a autora vê nos novos movimentos sociais que se avolumam ao final dos anos sessenta e durante os anos setenta, um fator também atuante na inflexão ocorrida ${ }^{51}$.

A novidade, ou seja, a compreensão (militante e teórica) da participação como participação social, conseqüência do "clima de desilusão com os mecanismos participatórios tradicionais das democracias liberais e [da] emergência de novos grupos de interesse" (Cortes 1996 - b), fundamenta-se, como percebe a autora, no princípio (ou no valor) da autonomia da organização societária frente às instituições que conformam o establishment político. No caso da América Latina, tal princípio (ou valor) teria sido reforçado, naquele momento histórico, tanto pela expansão de

\footnotetext{
${ }^{49}$ É claro que a conceituação de participação como social não nega a dimensão política; muito menos é unívoca. A novidade, contudo, parece ter maior dificuldade (e menor pretensão) que sua antecessora, a participação política tout court, de encontrar um marco teórico no qual se abrigar.

50 Declinante participação pela via do voto, redução da confiança na representação parlamentar, afastamento dos partidos políticos de suas identidades programáticas, e outros desencantos, tornaram-se objetos de inúmeros estudos, assim como o crescente controle das corporações de negócios sobre a competição partidária, a influência dos arranjos corporativistas e o caráter cada vez mais tecnocrático das decisões em políticas públicas.

${ }^{51}$ Entre esses novos movimentos estariam Maio de 68 (em Paris), as organizações de moradores, ecológicas e de consumidores nos EUA, em países europeus e latino-americanos (CORTES, 1996-b). Mais recente, o Fórum Socia Mundial poderia ser incluído como espaço de convergência desses movimentos.
} 
movimentos emancipatórios em prol de "mudanças radicais no sistema político e econômico" (Gascón, Tamargo \& Carles 2005), nos anos 1960 principalmente, quanto pela inevitável identificação entre o establishment político e as ditaduras que ali permaneceram instaladas nas duas décadas subseqüentes ${ }^{52}$.

Mas um terceiro fator é, para CORTES (1996-b), também elucidativo da recente inflexão sofrida pelo conceito de participação: a reforma do Estado. Mudanças promovidas por vários governos nas estruturas burocráticas estatais, em função do contexto econômico internacional que emerge na segunda metade da década de 70, implicaram a delegação de funções à sociedade (e ao mercado), bem como a criação de mecanismos participatórios destinados a desburocratizar ou domesticar - os processos decisórios. Essa vertente da participação, social, passou a merecer a atenção dos formuladores de políticas e dos formuladores de teorias ao longo dos anos 90. Formuladores de políticas, situados em diferentes posições do espectro político, e formuladores de teorias, adeptos de diferentes matizes ideológicos no interior das ciências sociais, vêm se dedicando desde então a exaltar ou explicar a novidade. Mais um consenso se constituiu no universo das políticas públicas, agora em torno do tema participação, cada vez societalizado e cada vez menos politizado.

A concepção inovada de política social considera os três fatores apontados por CORTES (1996-b) e por isso requer a prática participativa. Mas participação de quem? Dos pobres, da comunidade (que já não é a sociedade como um todo), daqueles que precisam de alavancas para exercer suas individualidades. Daí que, acriticamente, conceitos díspares como capital social, empoderamento, responsabilidade social das empresas, gestão corporativa, terceiro setor, governança, passam a fazer parte do vocabulário da nova política social. Conceitos que se originam tanto de "novos campos" da ciência social - a socioeconomia, por exemplo -, ou da "descoberta de novas realidades" que se apresentam ao cientista social, quanto das modernas técnicas de administração.

A participação "social" constitui, indubitavelmente, uma prática de cidadania e sua formalização como procedimento afeto às políticas sociais descentralizadas é um dos traços democráticos da institucionalidade brasileira pós-88. Mas a garantia (formal) de voz aos pobres referenda também a suposição de que outras camadas da população dela prescindem porque dispõem do mecanismo de saída (HIRSCHMAN, 1973).

\footnotetext{
${ }^{52}$ Com efeito, os movimentos emancipatórios na América Latina dos anos 60 - no Brasil antes de 64 - tinham como objetivo geral a incorporação (na época o termo inclusão ainda não freqüentava o vocabulário da esquerda) das massas, dos oprimidos, dos explorados, dos trabalhadores e camponeses, etc., ao cenário político e ao mundo da vida "civilizada". A mobilização de tais setores, através de sindicatos, associações e partidos era tida como crucial para que pudessem vir a participar efetivamente da transformação que se julgava próxima. Já nos anos 80, o movimento pela democratização vai articular nitidamente a derrogação da institucionalidade autoritária à questão social, incluindo as bandeiras da descentralização e da participação. O imperativo da participação, então, não se dirigia mais a toda a sociedade e sim àqueles segmentos social e economicamente alijados. Até porque, como foi demonstrado pela literatura sobre processos decisórios sob o autoritarismo, as elites econômicas participavam, por vias informais e formais, das decisões então tomadas.
} 


\section{REVISTA Em Pauta}

Volume 6 - Número 23 - Julho de 2009

[ Voz, Alívio e Oportunidade ou a Política Social de Arquimedes no Brasil - VIANNA, M.L.T.W. \}

Políticas sociais como alavancas - voz, alívio e oportunidade para os pobres - compõem a novíssima concepção liberal da questão social e das formas de enfrentá-la. O ponto de apoio está no suposto consenso que dispensa o debate teórico. A mudança a alcançar é a inclusão. Confundindo inclusão com universalidade de direitos, deixam incólumes as razões estruturais que impõem a necessidade de tais alavancas, bem como a natureza do pulo que as ditas alavancas propiciam. Desvendar e discutir as premissas teóricas que fundamentam essa concepção é um desafio que tem sido menosprezado pelos cientistas sociais.

O aparente consenso em torno da inovação representada pela política social predominante hoje no Brasil denota um empobrecimento das ciências sociais no que concerne ao tema da questão social. Prolixa e empiricista, a ciência social que trata da pobreza revela a pobreza da ciência social. 


\section{REVISTA Em Pauta Volume 6 - Número 23 - Julho de 2009 [ Voz, Alívio e Oportunidade ou a Política Social de Arquimedes no Brasil - VIANNA, M.L.T.W. \} REFERÊNCIAS BIBLIOGRÁFICAS}

ARNSTEIN, Sherry R. A Ladder of citizen participation. JAIP, vol. 35,n. 4,July, 1969. p. 216-224.

ASHFORD, D. The emergence of the Welfare States. Oxford: Basil Blackwell, 1986. AZEVEDO, S. \& ANASTASIA, F. Governança, 'Accountability' e Responsividade. Revista de Economia Política, vol. 22, n. 1 (85) janeiro-março. São Paulo: s/ed, 2002.p. 79-97.

BALBACHEVSKY, E. "Stuart Mill: liberdade e representação". WEFFORT, F. (org). Os Clássicos da Política. Vol 2. São Paulo: Ática, 1989.

BANCO MUNDIAL. Relatório sobre o Desenvolvimento Mundial 2000/2001, Luta contra a Pobreza. Oxford: Oxford University Press, 2000.

CASTEL, Robert. As metamorfoses da questão social. Petrópolis: Vozes, 1998.

CONDÉ, E. Laços na diversidade: a Europa Social e o Welfare State em movimento (1992-2002). Tese de doutorado. Campinas: IE/UNICAMP, 2004.

CORTES, S. M. V. "As origens da participação na área da saúde". Saúde em Debate, n. 51. Londrina: Cebes, 1996 (a). p. 30-37.

CORTES, S. M. V. "Fóruns participatórios na área de saúde: teorias do Estado, participantes e modalidades de participação". Saúde em Debate, n. 49-50. Rio de Janeiro: Cebes, 1996 (b). p. 73-79.

COSTA, Flávio Moreira da (org.). Os 100 melhores contos de humor da literatura universal. Rio de Janeiro: Ediouro, 2001.

DAHL, R. Poliarchy. New Haven: Yale University Press, 1971.

DONZELOT, J. \& EPSTEIN, R. "Démocratie et participation: I'exemple de la renovation urbaine". Esprit, jul. 2006.

EASTON, D. The Political System. New York: Willey, 1953.

EASTON, D. Modalidades de análise política, Rio de Janeiro, Zahar, 1970.

ESPING-ANDERSEN, G. O Futuro do Welfare State na Nova Ordem Mundial. Lua Nova n. 35. São Paulo, CEDEC, 1995.

GASCÓN, S., TAMARGO, M.D.C. \& CARLES, M. Marco conceptual y metodológico sobre participación ciudadana en salud en el MERCOSUR ampliado. Fundación ISALUD, primer informe de avance, fev 2005.

GENTIL, D. L. A política fiscal e a falsa crise da seguridade social brasileira. Tese de doutorado. Rio de Janeiro:IE/UFRJ, 2006.

HAM, C. \& HILL, M. The policy process in the modern capitalist state. London; Prentice Hall, 1984.

HECLO, H. Modern Social Policies in Britain and Sweden. New Haven: Yale University Press, 1974.

HECLO,H. Policy analysis, British Journal of Political Science, vol. 2, n. 1, jan. Londres: s/ed., 1972. p. 88-108.

HIRHSMAN, A. Saída, voz e lealdade. São Paulo: Perspectiva, 1973.

JACOBI, P. R. Políticas sociais locais e os desafios da participação citadina. Ciência \& Saúde Coletiva, vol. 7, n. 3. São Paulo: Abrasco, 2002. 
\} Voz, Alívio e Oportunidade ou a Política Social de Arquimedes no Brasil - VIANNA, M.L.T.W. \}

LESSA, R. As razões da poliarquia. Jornal de Resenhas. São Paulo: Folha de São Paulo, 8 de novembro de 1997.

MACPHERSON, C. B. The Life and Times of Liberal Democracy. New York-Toronto -Melbourne: Oxford University Press, 1977.

MACPHERSON, C. B. La teoria política del individualismo posesivo. Barcelona: Fontanella, 1970.

MARSHALL, T. Cidadania, Classe Social e Status, Rio de Janeiro: Zahar, 1967.

MARSHALL, Theodore. Social Policy. Londres: Hutchinson University Library, 1975. MAURIEL. A. P. O. Combate à pobreza e desenvolvimento humano: impasses teóricos na construção da política social na atualidade. Tese de doutorado. Campinas: PPGCS/IFCH/UNICAMP, 2008.

MERCHIOR, J. G. O liberalismo antigo e moderno. Rio de Janeiro: Nova Fronteira, 1991.

OFFE, C. "A democracia partidária competitiva e o Welfare State Keynesiano: fatores de estabilidade e desorganização". Problemas Estruturais do Estado Capitalista, Rio de Janeiro: Tempo Brasileiro, 1984.

PAES e BARROS, Ricardo. A estabilidade inaceitável; desigualdade e pobreza no Brasil. Texto para discussão n. 800. Rio de Janeiro: IPEA, 2001.

PIVEN, F. \& CLOWARD. Regulating the Poor. New York: Vintage Books, 1971. PNUD. Relatório de Desenvolvimento Humano, PNUD. Nações Unidas, 1990. POLANYI, Karl. A grande transformação. Rio de Janeiro: Campus, 1980.

PRZEWORSKI, A. Capitalismo e social-democracia. São Paulo: Companhia das Letras, 1989

ROCHA, Sônia. Pobreza no Brasil; afinal, do que se trata? Rio de Janeiro: Editora FGV, 2003.

RUA, M. G. Análise de Políticas Públicas: conceitos básicos. RUA, M.G. \& VALLADÃO DE CARVALHO, M. I. (orgs) O Estudo da Política. Brasília: Paralelo 15, 1998. SZMRECSÁNYI, T. (org ) Keynes. São Paulo: Ática, 1978.

TAMPKE, J. "Bismarck's social legislation: a genuine breakthrough?" MOMMSEN, Wolfgang Justin (org). The Emergence of the Welfare State in Britain and Germany. Kent: Croom Helm Ltda, 1981.

TEIXEIRA, A. Do seguro à seguridade: a metamorfose inconclusa do Sistema Previdenciário Brasileiro. Texto para discussão, IE/UFRJ, n. 249. Rio de Janeiro: IE/UFRJ 1990.

TEIXEIRA, A. (org.). Utópicos, heréticos e malditos: os precursores do pensamento social de nossa época. Rio de Janeiro: Record, 2002.

UGÁ, V. A questão social como pobreza: crítica à conceituação neoliberal. Tese de Doutorado. Rio de Janeiro: IUPERJ, 2008.

VÁRNAGY, T. "O pensamento político de John Locke e o surgimento do liberalismo". BORIN, A. (org). Filosofia política moderna, de Hobbes a Marx. Buenos Aires/São Paulo:CLACSO/DCP-FFLCH-USP, 2006. Disponível em http:/bibliotecavirtual. clacso.org.

WERNECK VIANNA, M.L.T. A americanização (perversa) da seguridade social no Brasil. Revan, Rio de Janeiro, 1998. 


\section{REVISTA Em Pauta}

Volume 6 - Número 23 - Julho de 2009 \} Voz, Alívio e Oportunidade ou a Política Social de Arquimedes no Brasil - VIANNA, M.L.T.W. \}

WERNECK VIANNA, M.L.T. "A nova política social no Brasil: uma prática acima de qualquer suspeita teórica?" Praia Vermelha, n. 18. Rio de Janeiro: PPGSS/UFRJ, 2008. p. 120-145.

WERNECK VIANNA, M.L.T. ANTUNES, L \& CAVANTI, M. L. "Participação: de que estamos falando?" Revista Sociologias, n. 21. Porto Alegre: UFRGS, 2009. p. 218251.

Recebido em 20 de abril de 2009.

Aceito para publicação em 30 de maio de 2009. 